\title{
Willingness to donate eyes and its associated factors among adults in Gondar town, North West Ethiopia
}

\author{
Mohammed Seid Hussen ${ }^{1 *}$, Kbrom Legesse Gebreselassie ${ }^{1}$, Asamere Tsegaw Woredekal ${ }^{2}$ \\ and Nebiyat Feleke Adimassu ${ }^{1}$
}

\begin{abstract}
Background: In Ethiopia, there is a substantial mismatch between need and supply of corneal transplant. Although corneal transplantation service is affected by various factors, willingness to donate eyes is an essential indicator of its availability, accessibility, and acceptability. Therefore, this study aimed to determine the magnitude of willingness to donate eyes and its associated factors, which help to develop appropriate strategies that can address this undersupply and unmet need.
\end{abstract}

Methods: A community-based cross-sectional survey was conducted on 774 adults who were selected using multistage random sampling in Gondar town, North West, Ethiopia. The data were collected through interviews.

Results: In this survey, 774 adults with a median age of $30 \pm 14.33$ years participated. The proportion of willing to donate eyes was $37.6 \%$ [95\% Cl: 34.3\%-41.3\%]. It was positively associated with the religious belief of Christianity $[\mathrm{AOR}=1.73,95 \% \mathrm{Cl}: 1.08-2.75]$, having awareness about eye donation $[\mathrm{AOR}=1.38,95 \% \mathrm{Cl}: 1.01-1.92]$, educational level of high school [AOR $=2.90,95 \% \mathrm{Cl}: 1.72-4.90]$, and College/University [AOR $=2.23,95 \% \mathrm{Cl}: 1.28-3.87]$.

Conclusion: The magnitude of willingness to donate eyes was moderate and positively associated with the higher educational level and awareness. It is, therefore, strategic to plan awareness creation programs to mobilize the community.

Keywords: Willingness, Eye donation, Gondar, Ethiopia

\section{Background}

Globally, corneal blindness is the second most prevalent ocular condition, especially in developing countries. Bilateral corneal blindness accounts for $12 \%$ (4.9 million) of 39 million blind [1, 2]. In Ethiopia, 19.3\% of all blind cases are contributed by corneal blindness. It mainly results from trachoma, Xerophthalmia, use of harmful traditional eye medicines, onchocerciasis and ocular trauma $[2,3]$. Ultimately, the condition results in loss of productivity for those of young and middle age adult [4].

The best option to rehabilitate the impaired vision is a corneal transplantation worldwide. However, the potentially limiting factor in planning transplantation is the shortage of donated corneas. It is also aggravated by the

\footnotetext{
* Correspondence: mohamiaseid@gmail.com

${ }^{1}$ Department of Optometry, College of Medicine and Health Sciences,

University of Gondar, Gondar, Ethiopia

Full list of author information is available at the end of the article
}

availability of inefficient domestic eye bank, lack of potential donors and weak cooperation of close relatives to collect pledged cornea [5].

In developing countries, where the magnitude of corneal blindness is higher, the availability of donated corneas is very low. In Ethiopia, between 130 and 150 corneas are harvested yearly [5]. However, there are more than 300,000 blind people due to corneal disease. This depicts that there is a potential gap between demand and supply of corneal graft.

Some studies revealed that willingness to donate eyes and close relatives 'cooperativeness to donate pledged eyes is essential to ensure the corneal transplantation service [5]. In developed countries, the decision to be an organ donor is affected by relational ties, religious beliefs, previous exposure to a health care, cultural and family influences [6]. 
A study was done regarding willingness to donate eyes in central Ethiopia. However, the demographic distribution of central Ethiopia with respect to religion, cultural and social values is different from Northern Ethiopia. Thus, it is difficult to generalize this study. This indicates that there is a limitation of evidence regarding willingness to donate eyes in the area. It was, therefore, important to determine the magnitude of willingness to donate eyes and its associated factors. The finding of this study helps to develop strategies that can address this undersupply and unmet need.

\section{Methods}

\section{Study population and study design}

A community-based cross-sectional design study was employed. The study was conducted in Gondar town, North West Ethiopia, March 13, 2016. All adults aged $\geq 18$ years had equally likely chance to participate in this survey. Nevertheless, those adults who had corneal blindness in both eyes, and mental illness were excluded.

\section{Sample size determination}

The entire sample size was 825 , which was determined using the single population proportion formula. During computing the sample size, 95\% confidence level, the proportions of willing to donate eyes from a similar study conducted in central Ethiopia (57.9\%) [7], 5\% margin of error and $10 \%$ for non-response rate were assumed. Then the computed sample size was multiplied by the design effect of two for ensuring its representativeness. The study participants were selected using a multistage random sampling method.

\section{Data collection tool and procedures}

A structured hard copy questionnaire was utilized. It was derived from previous studies [7, 8]. The questionnaire comprised of 25 questions regarding knowledge about eye donation, willingness to donate eyes, and socio-demographic characteristics (Additional file 1). The questionnaire was first prepared in English language, then translated to Amharic and later back translated into the English language to maintain its consistency. The data were collected by trained optometrists through face to face interviews.

Willingness to donate eyes was categorized as willing if a subject had the interest to pledge to donate his/her eyes and unwilling if a subject was involuntary to pledge to donate his/her eyes or not decided.

Knowledge was also assessed by using 11 questions. Each correct response had a score of 1 and each wrong or 'do not know' response had a score of 0 . The sums of scores varied from 0 to 11 points. Finally, the overall knowledge was categorized using modified Bloom's cut off points as low, moderate and high if the scores were $<50 \%$
(0-5 points), between 50 and $79 \%$ (6-7 points) and from 80 to $100 \%$ (8-11 points), respectively [9].

\section{Data processing and statistical analysis}

After the data were checked for completeness, it was entered into EpiData version 3. Then it was exported to SPSS version 20. The descriptive parts of the data were summarized using measures of central tendency and dispersion. Associated factors for willingness to donate eyes were identified by using Binary logistic regressions. Thus, statistically significant association was considered for those factors with a $p$-value of less than 0.05. The analyzed data were organized and presented in a tabular and graphical form as per necessity.

\section{Ethical consideration}

Ethical approval was obtained from the School of Medicine; Ethical review committee, University of Gondar. The objective of the study was clearly described for each participant. Then written informed consent was received from each study participant. The survey participants were granted full right to cease or refuse to take part. Confidentiality was assured through keeping records and omitting any participants' identifiers.

\section{Results}

Socio-demographic and economic characteristics of the study subjects

In this study, the median age of the study participants was $30 \pm 14$. 33 years. Among 774 participants, $64.7 \%$ of them were females. The majority of the respondents were Christian (85.6\%) followed by Muslims (14.4\%). Thirty-five percent of the study participants have completed high school (Table 1).

\section{Participants' knowledge about eye donation}

Around $57 \%$ of the participants heard about eye donation before [95\% CI: $53.2 \%-60.2 \%$ ]. Their main source of information was a television (68.33\%) (Fig. 1). The median knowledge score point for those participants who had awareness was $6.0 \pm 1.76$ points. Overall, 23.7\% of the participants had a good level of knowledge about eye donation [95\% CI: 19.7\%-27.7\%] (Table 2).

\section{The proportion of willingness to donate eyes}

Among the total of 774 participants, $37.6 \%$ of them were willing to donate their eyes [95\% CI: $34.2 \%-41.1 \%]$. The majority of the study participants $(73.3 \%)$ were also willing to donate pledged close relatives' eyes upon the death of a person. Having a thought of that 'eye donation is pleased (69.75\%) and noble human act (19.7\%) were the primary reasons given for being willing to donate eyes (Table 3). Nevertheless, the most prevalent reasons for not donating their eyes were requiring further 
Table 1 Socio-demographic and economic characteristics of study participants, Gondar town, North West, Ethiopia, 2016 $(n=774)$

\begin{tabular}{|c|c|c|}
\hline Variables & Frequency & Percent \\
\hline \multicolumn{3}{|l|}{ Age(year) } \\
\hline $18-30$ & 403 & 52.1 \\
\hline $31-43$ & 181 & 23.4 \\
\hline$\geq 44$ & 190 & 24.5 \\
\hline \multicolumn{3}{|l|}{ Sex } \\
\hline Female & 501 & 64.7 \\
\hline Male & 273 & 35.3 \\
\hline \multicolumn{3}{|l|}{ Religion } \\
\hline Christianity & 663 & 85.6 \\
\hline Islam & 111 & 14.4 \\
\hline \multicolumn{3}{|l|}{ Ethnicity } \\
\hline Amhara & 711 & 91.9 \\
\hline Tigrayan & 39 & 5 \\
\hline Qemant & 24 & 3.1 \\
\hline \multicolumn{3}{|l|}{ Marital status(currently) } \\
\hline Married & 401 & 51.8 \\
\hline Single & 274 & 35.4 \\
\hline Divorced & 52 & 6.7 \\
\hline Widow & 47 & 6.1 \\
\hline \multicolumn{3}{|l|}{ Educational level } \\
\hline No formal education & 114 & 14.8 \\
\hline Primary school & 121 & 15.6 \\
\hline High school & 273 & 35.3 \\
\hline College/university & 266 & 34.3 \\
\hline \multicolumn{3}{|l|}{ Occupation } \\
\hline Non health care professionals & 757 & 97.8 \\
\hline Health care professionals & 17 & 2.2 \\
\hline \multicolumn{3}{|l|}{ Monthly income(Birr) } \\
\hline$\leq 1000$ & 275 & 35.5 \\
\hline $1000-2000$ & 180 & 23.3 \\
\hline $2000-3000$ & 143 & 18.5 \\
\hline$>3000$ & 176 & 22.7 \\
\hline
\end{tabular}

Education categories: No formal education (can read and write or not), primary school (1-8th), high school (8-12th), and college/university (diploma, degree, and above)

Income categories: Income was categorized based on country per capita income per month of Ethiopia (997 Ethiopian Birr), as follow, $\leq 1000,1000$ $2000,2000-3000$ and $>3000$

information to decide (40.8\%); desiring to be entombed with their whole body (25.7\%) and religious restriction (15.1\%) (Fig. 2).

\section{Associated factors of willingness to donate eyes}

In a multivariable binary logistic regression, only religion, educational level, and awareness were associated with

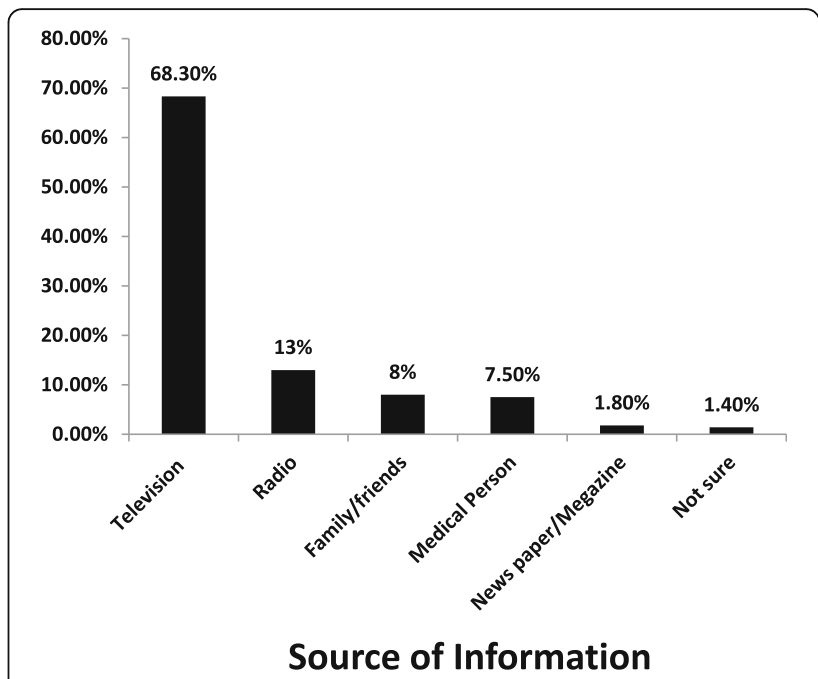

Fig. 1 Source of information for eye donation among adults in Gondar town, North West, Ethiopia, 2016

willingness to donate eyes. Thus, those participants who had the educational status of the high school, and College/University were 2.90 and 2.23 times more likely to be willing to donate their eyes than those who had no formal education, respectively. In addition, those who had awareness about eye donation were 1.38 times more likely to be willing to donate their eyes than those participants who had no awareness $[\mathrm{AOR}=1.38,95 \% \mathrm{CI}$ : 1.01-1.92] (Table 4).

\section{Discussion}

The proportion of willing to donate their eyes was $37.6 \%$, which is higher than the studies done in Melaka, Malaysia [8], and Ghana [10]. However, this result is lower than the studies done in South India [11], Australia [12], Singapore [13, 14], and Ethiopia [7]. The difference might be aroused from variation in literacy level, awareness level, availability of eye banks and study setting.

Table 2 Participants' awareness and knowledge about eye donation among adults in Gondar town, North West Ethiopia, 2016

\begin{tabular}{llll}
\hline Variables & Frequency & Percent & $95 \% \mathrm{Cl}$ \\
\hline Awareness $(n=774)$ & & & \\
Yes & 439 & 56.7 & {$[53.2 \%-60.2 \%]$} \\
No & 335 & 43.3 & {$[39.8 \%-46.8 \%]$}
\end{tabular}

Level of Knowledge ( $n=439)$

\begin{tabular}{llll} 
Low & 145 & 33 & {$[28.3 \%-37.7 \%]$} \\
Moderate & 190 & 43.3 & {$[38.7 \%-47.9 \%]$} \\
Good & 104 & 23.7 & {$[19.7 \%-27.7 \%]$} \\
\hline
\end{tabular}


Table 3 Willingness to donate eyes and perceived reasons, among adults in Gondar town, North West, Ethiopia, 2016 $(n=774)$

\begin{tabular}{|c|c|c|c|}
\hline Variables & Frequency & Percent & $95 \% \mathrm{Cl}$ \\
\hline \multicolumn{4}{|l|}{ Willingness to donate own eyes } \\
\hline Yes & 291 & 37.6 & {$[34.2 \%-41.1 \%]$} \\
\hline No & 483 & 62.4 & [59.98\%-65.8\%] \\
\hline \multicolumn{4}{|c|}{ Willingness to donate close relatives' eyes } \\
\hline Yes & 567 & 73.3 & {$[70.2 \%-76.4 \%]$} \\
\hline No & 207 & 26.7 & {$[23.6 \%-29.8 \%]$} \\
\hline \multicolumn{4}{|c|}{ Reasons for being willing to donate eyes $(n=291)$} \\
\hline $\begin{array}{l}\text { It is pleased to help blind } \\
\text { person }\end{array}$ & 203 & 69.75 & {$[64.5 \%-75.1 \%]$} \\
\hline Eye donation is noble work & 57 & 19.60 & {$[15.0 \%-24.2 \%]$} \\
\hline $\begin{array}{l}\text { It is both noble and a pleasure } \\
\text { activity }\end{array}$ & 23 & 7.90 & {$[4.8 \%-11.0 \%]$} \\
\hline $\begin{array}{l}\text { My eyes are not useful after } \\
\text { my death }\end{array}$ & 8 & 2.75 & {$[0.95 \%-4.62 \%]$} \\
\hline
\end{tabular}

It was also found that having a thought of that 'eye donation is pleased (69.75\%) and a noble act (19.7\%) was the main reasons given for being willing to donate eyes. Similar results were reported from previous studies done in Singapore [13] and central Ethiopia [7]. It indicates that a person's altruistic values to achieve a desired goal of life will matter a person's decision to donate eyes.

Since the decision to be an organ donor requires detail information about religious doctrine, cultural and social values [6], 40.8\% of unwilling participants required additional information to make their decision. This finding depicts that maximum efforts need to be exerted to provide a detailed information about eye donation to shape

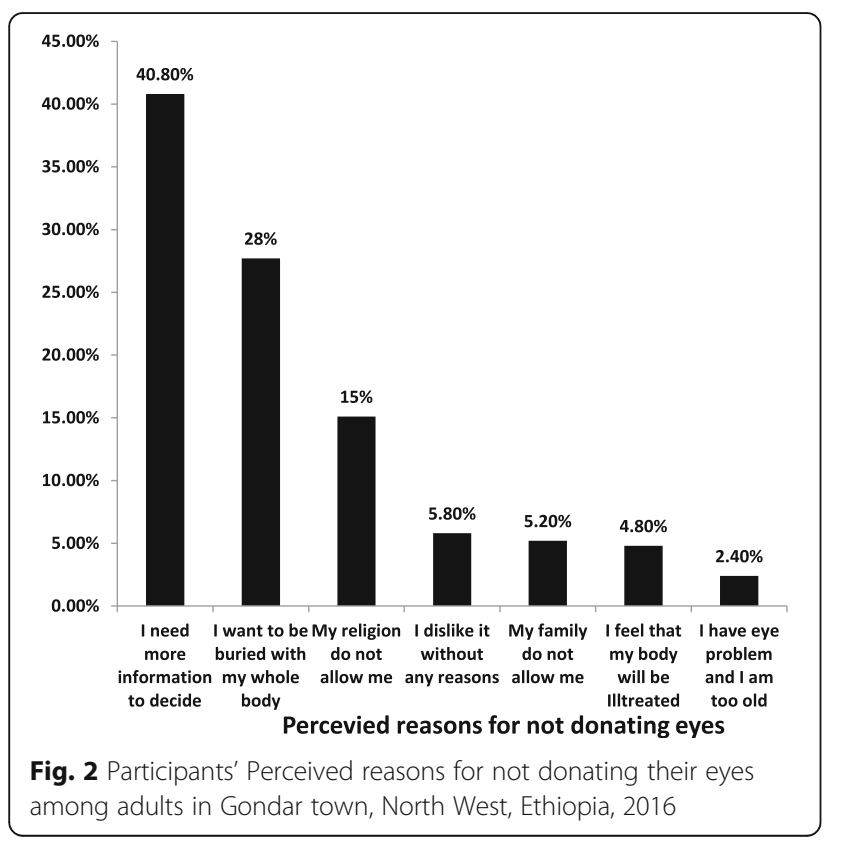

Table 4 Binary logistic regression output showing the effect of different variables on willingness to donate own eyes among adults, Gondar town, Northwest Ethiopia, 2016

\begin{tabular}{|c|c|c|c|c|}
\hline \multirow[t]{2}{*}{ Variables } & \multicolumn{4}{|c|}{ Willingness to donate eyes } \\
\hline & Yes & No & $\begin{array}{l}\text { Crude OR } \\
(95 \% \mathrm{Cl})\end{array}$ & $\begin{array}{l}\text { Adjusted OR } \\
(95 \% \mathrm{Cl})\end{array}$ \\
\hline \multicolumn{5}{|l|}{ Age (year) } \\
\hline $18-30$ & 157 & 246 & $1.35(0.94,1.940)$ & $1.04(0.65,1.63)$ \\
\hline $31-43$ & 73 & 108 & $1.43(0.93,2.18)$ & $1.09(0.68,1.76)$ \\
\hline$\geq 44$ & 61 & 129 & 1.00 & 1.00 \\
\hline \multicolumn{5}{|l|}{ Marital status } \\
\hline Single & 106 & 168 & 1.00 & 1.00 \\
\hline Married & 157 & 244 & $1.02(0.74,1.39)$ & $1.11(0.72,1.59)$ \\
\hline Divorced & 16 & 36 & $0.7(0.37,1.33)$ & $0.92(0.45,1.85)$ \\
\hline Widow & 12 & 35 & $0.54(0.27,1.09)$ & $1.01(0.44,2.33)$ \\
\hline \multicolumn{5}{|l|}{ Ethnicity } \\
\hline Amhara & 260 & 451 & 1.00 & 1.00 \\
\hline Tigrayan & 18 & 21 & $1.5(0.78,2.84)$ & $0.55(0.23,1.28)$ \\
\hline Qemant & 13 & 11 & $2.1(0.91,4.64)$ & $0.81(0.27,2.35)$ \\
\hline \multicolumn{5}{|l|}{ Religion } \\
\hline Christianity & 262 & 401 & $1.85(1.178,2.90)$ & $1.73(1.08,2.75)^{*}$ \\
\hline Islam & 29 & 82 & 1.00 & 1.00 \\
\hline Educational level & & & & $a * *$ \\
\hline No formal education & 24 & 90 & 1.00 & 1.00 \\
\hline Primary school & 33 & 88 & $1.41(0.77,2.57)$ & $1.39(0.76,2.57)$ \\
\hline High school & 122 & 151 & $3.03(1.82,5.04)$ & $2.90(1.72,4.90)^{* *}$ \\
\hline College/university & 112 & 154 & $2.73(1.64,4.55)$ & $2.23(1.28,3.87)^{*}$ \\
\hline \multicolumn{5}{|l|}{ Monthly income(birr) } \\
\hline$\leq 1000$ & 97 & 178 & 1.00 & 1.00 \\
\hline $1000-2000$ & 61 & 119 & $0.94(0.63,1.39)$ & $0.77(0.51,1.18)$ \\
\hline $2000-3000$ & 47 & 96 & $0.89(0.58,1.37)$ & $0.69(0.44,1.10)$ \\
\hline$>3000$ & 86 & 90 & $1.75(1.19,2.58)$ & $1.34(0.86,2.05)$ \\
\hline \multicolumn{5}{|l|}{ Awareness } \\
\hline Yes & 186 & 253 & $1.61(1.19,2.17)$ & $1.38(1.01,1.92)^{*}$ \\
\hline No & 105 & 230 & 1.00 & 1.00 \\
\hline
\end{tabular}

their attitude. The next cited reasons for not willing to donate their eyes were having a thought of to be buried with their whole body (25.7\%) and religious restriction (15.1\%). The origin of such reasons may be related to religious or cultural values. It was likewise expressed in a way that cultural and religious beliefs may be interchangeable and some people may hold culturally specific beliefs, which are not bound to any particular religious doctrine [6].

In a multivariable binary logistic regression, religion, educational level, and awareness were associated with 
the willingness to donate eyes. Thus, those participants who had the educational status of the high school, and College/University were 2.90 and 2.23 times more likely being willing to donate their eyes than those who had no formal education, respectively. Similar findings were reported from studies done in Nanjing, China [15], Ghana [10] and Jimma University, Ethiopia [4]. This association may be because individuals with higher educational status may have the favorable knowledge and attitude towards organ donation. This explanation is more supported by a study done in Washington, USA [16]. However, a study from Melaka, Malaysia showed that educational status is not associated with the willingness to donate eyes [8]. These studies were institutional based. This may be the possible reason for the argument.

The association found between willingness to donate eye and awareness regarding eye donation is in accord with previous surveys done in Central Ethiopia [7], Jimma University, Ethiopia [4] and Singapore [13]. This result implicates that providing comprehensive information about eye donation is essential to motivate the community.

This study also found an association between willingness to donate eye \& religion of Christianity as compared to the religion of Islam. This result in line with studies from Singapore [13] and India [17]. Furthermore, this finding is backed up by a qualitative study done at Oxford University, USA [6].

In the present study, there was no any association between age and willingness to donate eyes. Studies conducted in India, Singapore, and Nanjing, China reported that willingness to donate eyes was significantly higher among the older age population $[14,18,19]$. Nevertheless, a study performed in urban India showed that willingness to donate eyes was significantly lower in older adult [17]. This dispute might be due to variation in age categorization.

Since the study is a community-based research with a large sample, a generalization to the target population is not questionable. It would also be highly magnificent if it had a qualitative component.

\section{Conclusions}

The magnitude of willingness to donate eyes found from this study was moderate. It was also found that educational status; awareness and religion were identified as a statistically significant factor. It is, therefore, strategic to plan awareness creation programs to mobilize the community.

\section{Additional file}

Additional file 1: English version of structured questionnaires. (DOC $73 \mathrm{~kb}$ )

\section{Acknowledgements}

We would like to acknowledge the University of Gondar for financial and technical support to carry on this inquiry. We would also like to thank Mr.Azeze Wubie, Mr.Gizachew Tilahun, and Mr. Mohammed Hassen, for their invaluable comments and encouragements.

\section{Ethical approval and consent to participate}

The ethical approval was obtained from the School of Medicine, Ethical review committee, University of Gondar. The aim of the study and its public health importance was described for each participant. The consent declared that participants' participation is voluntary. It also reported that there is no any risk through participating in this survey. Confidentiality was assured through anonymous. It was also clarified that they had full right to refuse from participating in this research and to withdraw at any time they wish. They would also have a full right to contact and ask the authors whenever they want. Eventually, they were kindly requested to impart their real response. If an individual was willing to take part, we accepted his/her signature before the interview.

\section{Funding}

The university of Gondar has provided financial support for designing of the study, field work, analysis and write up.

\section{Availability of data and materials}

The data collection tool we used is included in this manuscript. However, the data sets generated and analyzed for the current study are available from the corresponding author on reasonable request.

\section{Authors' contributions}

The principal investigator was $\mathrm{MH}$ who ran the overall research process starting from proposal development up to manuscript preparation. $\mathrm{KL}$ and NF have provided their practical comments on the design of the study and its analysis. A professional consultancy role during data collection tool development was contributed by AT. All authors read and approved the final manuscript.

\section{Consent for publication}

Consent for publication is not applicable because this study did not consist of individuals' data.

\section{Competing interests}

We, the authors, declare that we have no any competing interests.

\section{Publisher's Note}

Springer Nature remains neutral with regard to jurisdictional claims in published maps and institutional affiliations.

\section{Author details}

'Department of Optometry, College of Medicine and Health Sciences, University of Gondar, Gondar, Ethiopia. ${ }^{2}$ Department of Ophthalmology, College of Medicine and Health Sciences, University of Gondar, Gondar, Ethiopia.

Received: 8 July 2016 Accepted: 25 September 2017

Published online: 02 October 2017

\section{References}

1. Oliva MS, Schottman T, Gulati M. Turning the tide of corneal blindness. Indian J Ophthalmol. 2012;60(5):423-7.

2. Whitcher JP, Srinivasan M, Upadhyay MP. Corneal blindness: a global perspective. Bull World Health Organ. 2001;79(3):214-21.

3. Berhane Y, Worku A, Bejiga A, Adamu L, Alemayehu W, Bedri A, et al. Prevalence and causes of blindness and low vision in Ethiopia. Ethiop $J$ Health Dev. 2008;21(3):204-10.

4. Gelaw YAF. Socio-demographic correlates of attitude towards corneal donation among health science students and academic staff of Jimma University. Ethiop Med J. 2010;48(1):41-7.

5. Rao GN, Gopinathan U. Eye banking: an introduction. Community Eye Health. 2009:22(71):46-7.

6. Irving MJ, Tong A, Jan S, Cass A, Rose J, Chadban S, et al. Factors that influence the decision to be an organ donor: a systematic review of the qualitative literature. Nephrology Dialysis. Transplantation. 2012;27(6):2526-33. 
7. Gessesse G, Tilahun Y. Willingness to donate eyes and associated factors among adults in a rural community in Central Ethiopia. JOECSA. 2013;17(1):20-24.

8. Bhandary S, Khanna R, Rao KA, Rao LG, Lingam KD, Binu V. Eye donationawareness and willingness among attendants of patients at various clinics in Melaka, Malaysia. Indian J Ophthalmol. 2011;59(1):41.

9. Sadana A, Sushma M, Ch K, Lekha R, Dudala SR, Prabhu GR, et al. ASSESSMENT OF KNOWLEDGE AND ATTITUDE REGARDING EYE DONATION AMONG UNDERGRADUATE MEDICAL STUDENTS, TIRUPATI. IJMPS. 2014;4(9):16-24.

10. Ackuaku-Dogbe E, Abaidoo B. Eye Donation: Awareness and Willingness among Patients Attending a Tertiary Eye Center in Ghana. West Afr J Med. 2013;33(4):258-63.

11. Ronanki VR, Sheeladevi S, Ramachandran BP, Jalbert I. Awareness regarding eye donation among stakeholders in Srikakulam district in South India. BMC Ophthalmol. 2014;14(1):25.

12. Lawlor M, Kerridge I, Ankeny R, Dobbins T, Billson F. Specific unwillingness to donate eyes: the impact of disfigurement, knowledge, and procurement on corneal donation. Am J Transplant. 2010;10(3):657-63.

13. Yew Y, Saw S-M, Pan JC, Shen H, Lwin M, Yew M, et al. Knowledge and beliefs on corneal donation in Singapore adults. Br J Ophthalmol. 2005; 89(7):835-40.

14. Paraz CMA, Truong HTT, Sai DK, Cajucom-Uy HY, Chan CLL, Kassim SM. Knowledge and attitudes toward corneal donation among Singaporean youth: a cross-sectional study. Eye and Vision. 2016;3:17.

15. Chu T, Wang LN, Yu H, Zhang RY. Awareness of cornea donation of registered tissue donors in Nanjing. Chin Med Sci J. 2013;28(1):20-7.

16. TJ CV, Wong KA, Spigner C, Allen MD. Effects of classroom education on knowledge and attitudes regarding organ donation in ethnically diverse urban high schools. Clinical transplant. 2010;24(6):784-93.

17. Dandona R, Dandona L, Naduvilath TJ, McCarty CA, Rao GN. Awareness of eye donation in an urban population in India. Aust N Z J Ophthalmol. 1999;27(3-4):166-9.

18. Chu T, Wang LN, Yu H, Zhang RY. Awareness of cornea donation of registered tissue donors in Nanjing. Chin Med Sci J. 2013;28(1):20-7. Epub 2013/03/27

19. Krishnaiah S, Kovai V, Nutheti R, Shamanna B, Thomas R, Rao G. Awareness of eye donation in the rural population of India Indian J Ophthalmol. January 1, 2004. 73-78 p.

\section{Submit your next manuscript to BioMed Central and we will help you at every step:}

- We accept pre-submission inquiries

- Our selector tool helps you to find the most relevant journal

- We provide round the clock customer support

- Convenient online submission

- Thorough peer review

- Inclusion in PubMed and all major indexing services

- Maximum visibility for your research

Submit your manuscript at www.biomedcentral.com/submit

) Biomed Central 